\title{
Chytrid fungus parasitizing the wild amphibian Leptodactylus ocellatus (Anura: Leptodactylidae) in Argentina
}

\author{
Raúl A. Herrera ${ }^{1}$, Mónica M. Steciow ${ }^{1, *}$, Guillermo S. Natale ${ }^{2}$ \\ ${ }^{1}$ Instituto de Botánica Spegazzini, 53 N 477, (1900), La Plata, Buenos Aires, Argentina \\ ${ }^{2}$ CIMA, Centro de Investigación del Medio Ambiente, Departamento de Química, Facultad de Ciencias Exactas, UNLP, \\ Beca Doctoral Interna CONICET, 47 y 115 (1900) La Plata, Buenos Aires, Argentina
}

\begin{abstract}
The present contribution is the first report of parasitosis by a chytrid fungus in wild anuran amphibians in Argentina, as well as the first case of amphibian mortality documented to date in Argentina. We report the presence of the chytrid fungus in dead adult Leptodactylus ocellatus. It has been suggested that chytridiomycosis is the main cause of death in several amphibian populations worldwide. Our study demonstrates that chytridiomycosis afflicts L. ocellatus, a common widespread amphibian species, and is the first report of chytridiomycosis in the Argentinian lowlands. The occurrence at this latitude would indicate an extended distribution of this fungus in wildlife populations. It is also the first report of amphibian mortality due to chytrid fungus in our country. It is noteworthy that the site of collection is situated very close to sea level in a temperate climate zone and that this represents the southernmost record for South American wild amphibians.
\end{abstract}

KEY WORDS: Chytridiomycosis $\cdot$ Leptodactylus ocellatus $\cdot$ First report $\cdot$ Argentina

\section{INTRODUCTION}

Chytridiomycosis is an example of an emerging infectious disease in amphibians (Daszak et al. 1999, 2000, 2003, Dobson \& Foufopoulos 2001). It was described both in wild (Berger et al. 1998, Bosch et al. 2001) and captive amphibians (Pessier et al. 1999, Mutschmann et al. 2000) as a new cutaneous disease (Pessier et al. 1999) caused by the fungal agent Batrachochytrium dendrobatidis (Longcore et al. 1999).

This disease has been suggested as one of the possible causes for the decrease in the size of in amphibian populations worldwide (Berger et al. 1998, Daszak et al. 1999, Muths et al. 2003). It has also been indicated as the cause of mortalities in bullfrog Rana catesbeiana farming facilities, and the possible role of this species as a disease vector for wild amphibian populations has been pointed out as a serious threat for the conservation of anurans (Mazzoni et al. 2003).
Although different hypotheses about the effects of this disease on amphibians have been advanced, the mechanism by which this organism kills its host remains unclear (Berger et al. 1998, Pessier et al. 1999). Apart from this, little is known about the role of the amphibians in the life-cycle of Batrachochytrium dendrobatidis; however, diverse studies have contributed to the knowledge of the biology of the fungus (Piotrowski et al. 2004).

Since the first report of this disease (Berger et al. 1998), evidence of chytridiomycosis has been found in more than 90 amphibian species on the continents of North America, South America, Australia, South Africa and Europe (Daszak et al. 2003, Hopkins \& Channing 2003, Speare \& Berger 2004). Even if the rise in the number of reported incidents of the disease may be partly attributed to an increase in worldwide research on the subject, it is still significant, since the outbreaks occurring in the wild represent a major threat for the 
worldwide conservation of fauna (Daszak et al. 2000, Dobson \& Foufopoulos 2001).

The large surface area of South America and its topographic features give rise to a wide array of climates and vegetation patterns that offer a variety of habitats, exploited by 1742 amphibian species (39\% of the global species richness), making the South American batrachofauna the richest in the world (Duellman 1999). However, few data are available on the status of amphibian populations in the southern regions of South America, such as Peru, Chile and Argentina (Anonymous 1999).

In South America, the disease was first detected in Ecuador as a result of the analysis of anurans collected between 1980 and 1998 (Ron \& Merino 2000); it was detected in Venezuela in a specimen of Atelopus cruciger collected in 1986 (Bonaccorso et al. 2003). In 1999 Mazzoni et al. (2003) reported the disease in a commercial farming facility for Rana catesbeiana in Uruguay. Recently, Seimon et al. (2005) reported the most recent occurrence for South America in tadpoles and adults of Telmatobius marmoratus.

Although there are 167 anuran species in 7 families in Argentina (Lavilla et al. 2000), the degree of incidence of fungal diseases among natural populations of autochthonous species (Lavilla 2001) has never been studied. The purpose of the present work is to report the first case of chytridiomycosis in Argentina, with a description of its epidemiologic features and of some aspects of the host Leptodactylus ocellatus (Anura: Leptodactylidae). The anuran community in the studied area, the site of the chytridiomycosis outbreak, comprises 14 species belonging to 4 families (Leptodactylidae, Bufonidae, Pseudidae and Hylidae), representing $51 \%$ of the total anuran species that inhabit the province of Buenos Aires.

Leptodactylus ocellatus is a well-known neotropical frog. It is wild-captured for human consumption (Cei 1980). It is also the most popular 'lab frog': large numbers of individuals are used for dissection and experimentation in biology courses and research laboratories (Duellman 1999) throughout Argentina and Brazil. Its conservation status is 'commercially endangered' (Lavilla \& Cei 2001). This species is found mainly in the eastern Amazon-Guiana region and occurs in CerradoCaatinga-Chaco and Pampean-Monte (Duellman 1999). In Argentina, the distribution of this almost littoral species extends from the Misiones to the Buenos Aires province and up to the northern borders of the Río Negro province. It is a typical inhabitant of marshes and streams, from sea level up to about 1000 to $1200 \mathrm{~m}$ in the pampean mountain ranges (Cei 1980). These are active and vigorous frogs, and due to their wide trophic range, they have been classified as generalist consumers (Gallardo 1958, 1964, Martori et al. 1983, Basso
1990). The breeding period extends from September to December (Sona et al. 1989), coinciding with the spring season, when temperatures increase and water is most abundant. During the breeding season the eggs are laid in foam nests on the water surface, usually in shallow ponds or sheltered lagoons. The foam nests dissolve after a few days and the tadpoles adhere to submerged plants. The adults show definite epimeletic behavior toward the tadpoles, which are gregarious and display etepimeletic behavior towards the adults (Gallardo 1974). The larval period lasts for about $1.5 \mathrm{mo}$, and the metamorphosis coincides with the drying of the seasonal ponds in this region.

Other parasites that have been reported for Leptodactylus ocellatus include Hannemania minor (Alzuet \& Mauri 1985), frequently observed in this and other species of the region, as well as various species of nematodes and trematodes (Baker \& Vaucher 1985, 1986, Kohn \& Fernandez 1988, Rodrigues et al. 1990, Paraense 1992).

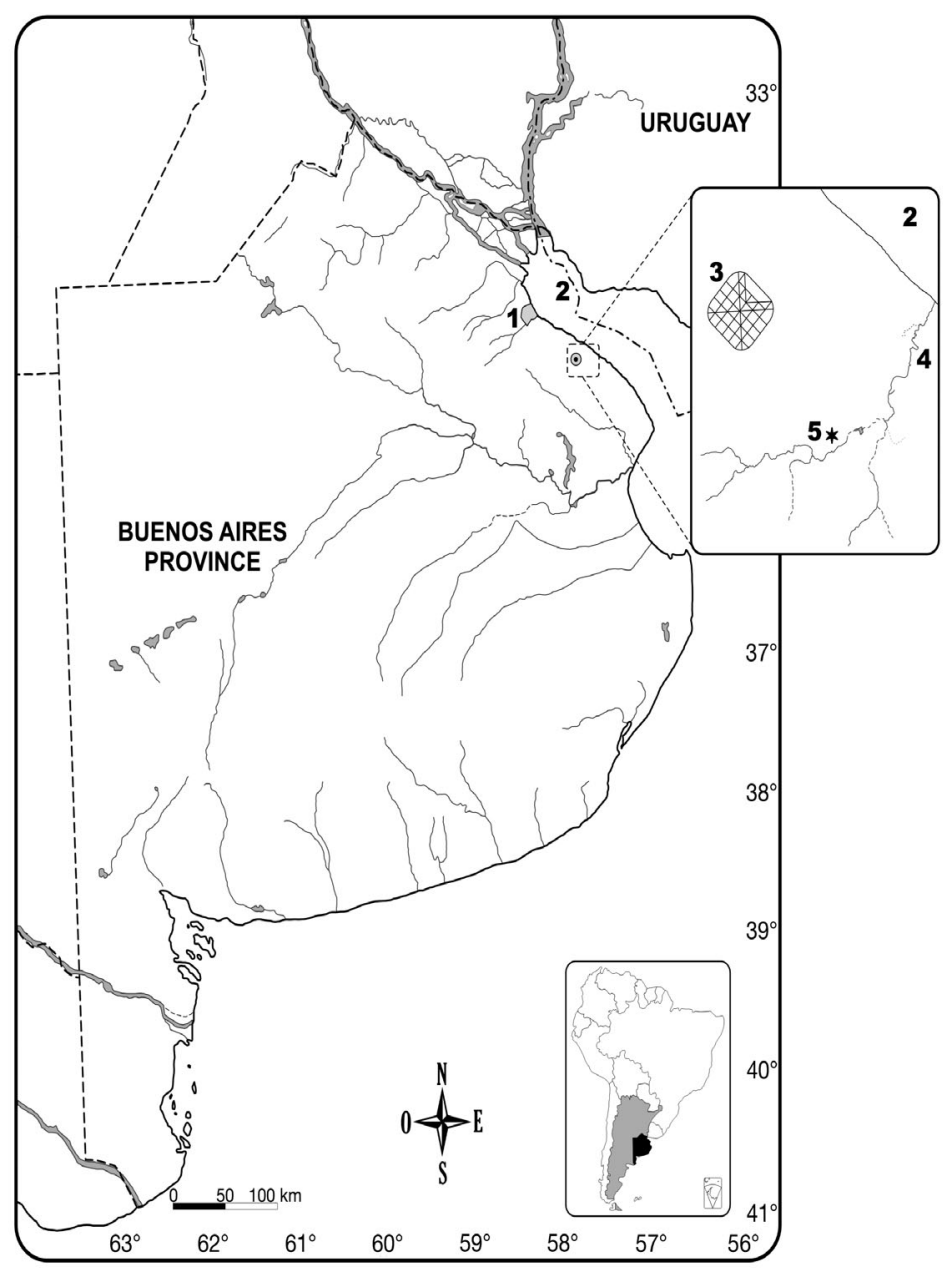

Fig. 1. Area under investigation. 1: Buenos Aires city; 2: Río de La Plata; 3: La Plata city; 4: 'El Pescado' creek; 5: area studied 


\section{MATERIALS AND METHODS}

The area under study is situated in the eastern part of the Buenos Aires province, on the outskirts of La Plata city (Fig. 1), from a hydrographic viewpoint part of the El Pescado creek flood valley. This watercourse is one of the permanent streams which are typical of the region, running eastward as part of the fluvial system that drains into the southwestern sector of the Río de la Plata. El Pescado creek is $36 \mathrm{~km}$ long (Ronco et al. 2001) and has a drainage basin of approx. $80 \mathrm{~km}^{2}$. The flood valleys are dominated by grass steppes characteristic of the Eastern Pampean District of the Pampean Phytogeographic Province (Cabrera 1976); semi-permanent ponds that are more or less connected with the creek develop periodically, offering ample habitat diversity. According to Köpen's classification, the climate is 'temperate-humid'; rainfall occurs throughout the year, more intensely in spring and autumn. Frosts occur in winter, and the minimum temperatures are recorded in July (Estudios de Aguas Subterráneas del NorEste [E.A.S.NE] 1970). The site of collection is situated halfway along the course of El Pescado creek $\left(35^{\circ} 1^{\prime} \mathrm{S}, 57^{\circ} 51^{\prime} \mathrm{W}\right), 11 \mathrm{~m}$ above sea level (m.a.s.l.) (Instituto Geográfico Militar Topographic Map 3557-20-1). This site has been under continuous study since 1998 by G. S. Natale within the context of his $\mathrm{PhD}$ thesis project.

Upon finding dead Leptodactylus ocellatus individuals (4 July 2002), a detailed survey of the area during the winter season was designed with the goal of documenting and quantifying the presence of dead or dying anurans of the diverse species of this community. Once collected, the specimens were carried to the laboratory, where their general condition was assessed and where they were examined for macroscopic evidence of disease. Ventral pelvic and hindlimb skin was excised from selected specimens after fixation in 10\% formalin and then paraffin-embedded for histological analysis. For this purpose, $5 \mu \mathrm{m}$ thick tissue sections were cut, stained with hematoxylin and eosin and examined under optical microscope to detect the presence of chytrid fungus. The diagnosis of chytridiomycosis was made according to the guidelines provided by Berger et al. (1999).

\section{RESULTS}

We found 11 dead adult Leptodactylus ocellatus individuals in the course of the survey carried out at the above site. Some of these were found on the banks of the ponds that are habitually used as breeding sites, whereas others were found in the grasslands that grow along El Pescado creek. The results of the laboratory diagnosis of the specimens' general condition are shown in Table 1.

Upon histological examination, fungal infection, indicated by the presence of chytrid fungal sporangia in the keratinized layer as described in previous investigations (Berger et al. 1998, Pessier et al. 1999, Seimon et al. 2005), was found in 4 specimens.

Our diagnosis of chytridiomycosis was based on several morphological criteria, including the presence of oval to spherical zoosporangia found mainly within the stratum corneum, associated hyperkeratosis, the absence of hyphae, the presence of various developmental stages of the chytrid, epidermal thickening, and areas of focal erosion adjacent to the infection. In addition, the cell walls of the observed zoosporangia were thin, smooth and uniform, and the presence of a discharge tube, by means of which the zoospores may escape, was detected. It was often possible to identify the zoospores as small basophilic masses within the sporangia. This morphological analysis agrees with the description of Batrachochytrium dendrobatidis given by Longcore et al. (1999).

We identified 2 different stages of infection: slight and severe, which were observed in 3 individuals and 1 individual, respectively. In the cases of slight infection (Fig. 2), focal erosions, containing clusters of between 4 and 10 spherical and oval sporangia of chytrid fungus, appeared in the superficial and keratinized layer of the epidermis, the stratum corneum. In the severe cases (Fig. 3), scattered sporangia were observed on the entire epithelial surface, restricted to the stratum corneum; generalized hyperkeratosis was also observed.

The majority of the sporangia were empty, presenting a thin uniform wall and a clear center. Discharge tubes, which allow the escape of mature zoospores through their openings, were evident in some sporangia. Some of the sporangia were divided by an internal

Table 1. Leptodactylus ocellatus. Laboratory diagnosis of specimens condition. Six individuals were in an advanced state of decomposition and were not considered in the diagnosis. Three individuals (SP001-SP003) showed post-mortem injuries caused by predators

\begin{tabular}{|c|c|c|c|c|c|}
\hline $\begin{array}{l}\text { Collection } \\
\text { no. }\end{array}$ & $\begin{array}{c}\text { Date of } \\
\text { collection }\end{array}$ & $\begin{array}{c}\text { General } \\
\text { condition }\end{array}$ & Sample & Diagnosis & Infection \\
\hline SP004 & 6 Jul 02 & Good & Hindlimb & Positive & Slight \\
\hline SP001 & 9 Jul 02 & Good & Pelvic-hindlimb & Positive & Slight \\
\hline SP002 & 9 Jul 02 & Good & Pelvic & Negative & - \\
\hline SP003 & 9 Jul 02 & Good & Pelvic-hindlimb & Positive & Slight \\
\hline SP004 & 4 Aug 02 & Good & Pelvic-hindlimb & Positive & Severe \\
\hline
\end{tabular}




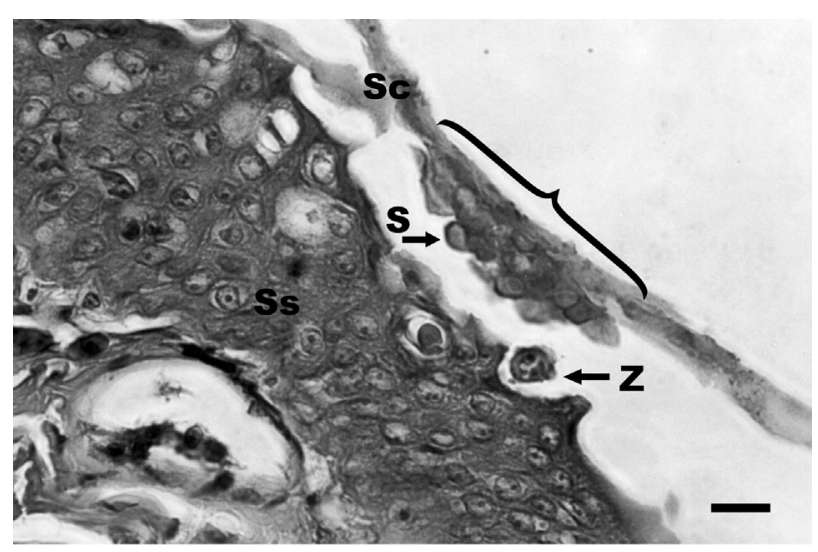

Fig. 2. Chytrid fungus in Leptodactylus ocellatus. Clusters of sporangia in stratum corneum, possibly in the initial infection stage (bracket). Sc: stratum corneum; Ss: stratum spinosum; S: sporangia; Z: zoospores within sporangium. Scale bar $=20 \mu \mathrm{m}$

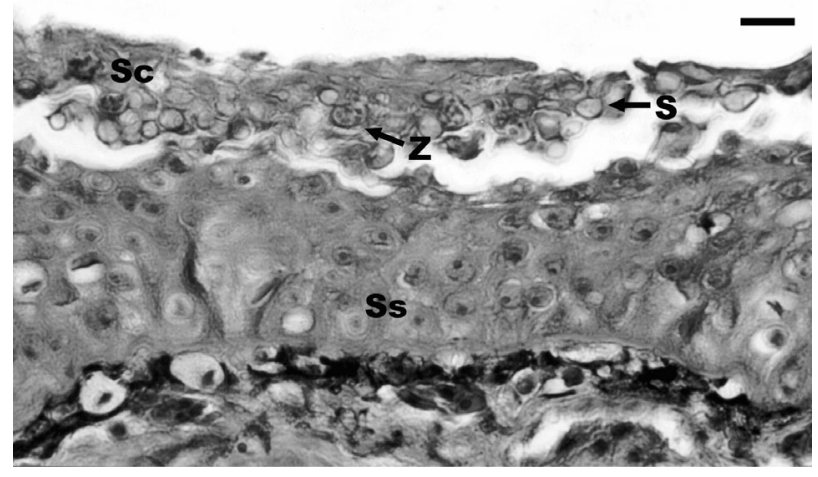

Fig. 3. Chytrid fungus in Leptodactylus ocellatus. Histological section showing extensive infection of ventral hindlimb skin. The stratum corneum is thickened due to infection by the chytrid parasite. Sc: stratum corneum; Ss: stratum spinosum; S: sporangia; Z: zoospores within sporangium. Scale bar $=20 \mu \mathrm{m}$

septum, in agreement with the condition observed in previous studies (Pessier et al. 1999). A few sporangia contained intracellular zoospores that displayed basophilic staining. The size of the sporangia was 7 to $12 \mu \mathrm{m}$.

\section{DISCUSSION AND CONCLUSIONS}

The results of the present study confirm the presence of the chytrid fungus in 4 Leptodactylus ocellatus individuals belonging to the anuran community that inhabits the area under investigation. This is the first record of a chytrid fungus parasitizing a wild anuran in Argentina and this is the most southern distribution of this parasite reported in South America.

The monitored survey carried out in a well-defined area also made it possible to document the first record of anuran mortality in the province of Buenos Aires. In South America, this fungus has previously only been found in Uruguay in captive North American bullfrogs Rana catesbeiana farmed for the international restaurant trade (Mazzoni et al. 2003). In the latter study, it was suggested that $R$. catesbeiana may be acting as a vector of chytridiomycosis into wild native anuran populations. However, no records of occurrence of this disease in any of the certified farming facilities in the area studied were found. Moreover, no feral individuals of this exotic species have been recorded in the province of Buenos Aires.

Our finding of dead amphibians during the winter season agrees with previous observations that many deaths from chytridiomycosis occur either during the cooler time of the year at any given location or in populations inhabiting high-altitude regions (Berger et al. 1998, Lips 1998, 1999, Bosch et al. 2001, Bradley et al. 2002). However, it should be emphasized that the present finding occurred in mid-winter (July), when annual temperatures are at their lowest, in contrast with other documented cases (Daszak et al. 1999, Bradley et al. 2002) in which the outbreak occurred during the late winter and early spring, when temperatures were rising.

Piotrowski et al. (2004) found that the optimal temperature for the development of the fungus is 17 to $25^{\circ} \mathrm{C}$ in laboratory conditions; however, Batrachochytrium dendrobatidis can grow within a wide range of temperatures ( 4 to $25^{\circ} \mathrm{C}$ ). Despite this information, it has not yet been possible to establish the complete lifecycle of this pathogen in the area. Because anurans are not normally active during the winter, there are no available hosts for the fungus to infect during this season, even if other environmental variables are optimal for fungal growth.

It is also worth remarking that the collection site is situated close to sea level (11 m.a.s.l.), in contrast with most other records to date, which are based on collection sites from higher locations, from 500 to over 4000 m.a.s.l.

The site of this chytridiomycosis outbreak has been monitored continuously since 1998, and had been visited on other occasions prior to that date. Consequently, the 2002 amphibian mortality is likely a new occurrence. This may permit us to date the moment at which the disease emerged more accurately, in accordance with the proposal of Daszak et al. (2003). Our finding of 2 infection stages agrees with the observations made by Piotrowski et al. (2004); in the present case an initial $(n=3)$ and an advanced $(n=1)$ stage of infection were distinguished.

We conclude that some of the individuals $(n=4)$ were affected by chytridiomycosis, but the studies that were carried out are not sufficient to establish the 
cause of death. Nevertheless, we believe that chytridiomycosis was not the only cause of mortality, but rather that there were a number of synergistically interacting factors. In most individuals, the degree of infection was not severe, and the animals did not exhibit the external lesions that are indicative of advanced disease. Possibly the low temperatures and frosts recorded on the days when mortality occurred were factors contributing to the death of these specimens.

Due to the characteristics of its basin, El Pescado creek could be acting as a means to disperse the disease into other communities in the area. If this were the case, we would expect the present finding to be non-random and the disease to be present throughout the entire area of influence of this watercourse.

As this species, the 'rana criolla' Leptodactylus ocellatus, is widespread in our country, further studies in the region are necessary in order to determine whether the presence of chytrid is natural or whether it has been introduced by human activities, to obtain information on the prevalence and habitat specialization of the chytrid fungus in different areas of Argentina, and also to study the possible infection of other species belonging to the local anuran community.

Acknowledgements. Mr. P. E. Topa is gratefully acknowledged for his valuable technical assistance. The authors wish to thank Dr. T. A. DeVries for her meaningful comments. We greatly appreciate the financial support from the DAPTF Seed Grant for the study of chytridiomycosis in Argentine amphibian populations, the Argentine National Research Council (CONICET) (PEI 6485/01) and the National University of La Plata (N 11/333 Project).

\section{LITERATURE CITED}

Alzuet ADB, Mauri RA 1987 (1985) Acaros Trombiculidae del género Hannemania Oudemans, endoparásitos de anfibios. Rev Soc Entomol Argent 44(2):111-116

Anonymous (1999) Population declines of amphibians in Latin America. A report on three international workshops held to assess the problem and prioritize needs. Smithsonian Tropical Research Institute, Washington, DC, p 1-34

Baker MR, Vaucher C (1985) Parasitic helminths from Paraguay. Systematic position of Oxyascaris Travassos, 1920 (Nematoda, Cosmocercoidea). Rev Suisse Zool 92(2):303-310

Baker MR, Vaucher C, (1986) Parasitic helmiths from Paraguay. 12. Aplectana Railliet \& Henry, 1912 (Nematoda: Cosmocercoidea) from frogs. Rev Suisse Zool 93(3):607-616

Basso NG (1990) Estrategias adaptativas en una comunidad subtropical de anuros. Cuad Herpetología Ser Monografías 1:70

Berger L, Speare R, Daszak P, Green DE and 10 others (1998) Chytridiomycosis causes amphibian mortality associated with population declines in the rain forests of Australia and Central America. Proc Natl Acad Sci USA 95:9031-9036
Berger L, Speare R, Kent A (1999) Diagnosis of chytridiomycosis in amphibians by histologic examination. Available atwww.jcu.edu.au/school/phtm/PHTM/frogs/histo/chhisto. htm, November 1999

Bonaccorso E, Guayasamin JM, Méndez D, Speare R (2000) Chytridiomycosis as a possible cause of population declines in Atelopus cruciger (Anura: Bufonidae). Herpetol Rev 34:331-334

Bosch J, Martinez-Solano I, Garcia-Parris M (2001) Evidence of a chytrid fungus infection involved in the decline of the common midwife toad (Alytes obstetricans) in protected areas of Central Spain. Biol Conserv 97:331-337

Bradley GA, Rosen PC, Sredl MJ, Jones TR (2002) Chytridiomycosis in native Arizona frogs. J Wildl Dis 38:206-212

Cabrera AL (1976) Regiones fitogeográficas de Argentina. Encicl Arg Agric Jard 2(1):1-85

Cei JM (1980) Amphibians of Argentina. Monit Zool Ital (NS) Monogr 2:XII+609

Daszak P, Berger L, Cunningham AA, Hyatt AD, Green DE, Speare R (1999) Emerging infectious diseases and amphibian population declines. Emerg Infect Dis 5(6): 735-748

Daszak P, Cunningham AA, Hyatt AD (2000) Emerging infectious diseases of wildlife threats to biodiversity and human health. Science 287:443-449

Daszak P, Cunningham AA, Hyatt AD (2003) Infectious disease and amphibian population declines. Divers Distrib 9:141-150

Dobson A, Foufopoulos J (2001) Emerging infectious pathogens of wildlife. Phil Trans R Soc Lond B 356: 1001-1012

Duellman WE (1999) Global distribution of amphibians: patterns, conservation and future challenges. In: Duellman WE (ed) Patterns of distribution of amphibians, a global perspective. The Johns Hopkins University Press, Baltimore, MD, p 1-30

Estudios de Aguas Subterráneas del NorEste (E.A.S.NE) (1970) Algunos Caracteres Geohidrológicos de las cuencas que se extienden desde el Arroyo El Pescado hasta el Arroyo San Felipe. Consejo Federal de Inversiones, Gonnet

Gallardo JM (1958) Observaciones sobre el comportamiento de algunos anfibios argentinos. Cienc Investig 14(1011):460-465

Gallardo JM (1964) Consideraciones sobre Leptodactylus ocellatus (L.) (Amphibia, Anura) y especies aliadas. Physis 24(68):373-384

Gallardo JM (1974) Anfibios de los alrededores de Buenos Aires. Eudeba, Buenos Aires

Hopkins S, Channing A (2003) Chytrid fungus in Northern and Western Cape frog populations, South Africa. Herpetol Rev 34:334-336

Kohn A, Fernández BMM (1988) Revision of the Brazilian species of the genus Halipegus Loos, 1899 (Trematoda: Dendrogenidae). Syst Parasitol 11(2):129-137

Lavilla EO (2001) Amenazas, declinaciones poblacionales y extinciones en anfibios argentinos. Cuad Herpetol 15(1): 59-82

Lavilla EO, Cei JM (2001). Amphibians of Argentina. A second update, 1987-1997. Monogr Mus Reg Sci Nat Torino $28: 177+8$ pls

Lavilla EO, Ponssa ML, Baldo D, Basso N and 11 others (2000) Categorización de los Anfibios de Argentina. In: Lavilla EO, Richard E, Scrocchi GJ (eds) Categorización de los Anfibios y Reptiles de la República Argentina. Asoc Herpetol Argentina, Tucumán, p 11-34

Lips KR (1998) Decline of a tropical montane amphibian fauna. Conserv Biol 12:106-117 
Lips KR (1999) Mass mortality and population declines of anuran an upland site in Western Panama. Conserv Biol 13:117-125

Longcore JC, Pessier AP, Nichols DK (1999) Batrachochytrium dendrobatidis gen. et sp. nov., a chytrid pathogenic to amphibians. Mycologia 91:219-227

Martori R, Di Tada I, Bedano J (1983) Tácticas tróficas de la batracofauna de embalse de Río Tercero (Córdoba, Argentina). Bol Asoc Herpetol Argentina 1(3):10

Mazzoni R, Cunningham AA, Daszak P, Apolo A, Perdomo E, Speranza G (2003) Emerging pathogen of wild amphibians in frogs (Rana catesbeiana) farmed for international trade. Emerg Infect Dis 9(8):995-998

Muths E, Corn PS, Pessier AP, Green DE (2003) Evidence for disease-related amphibian decline in Colorado. Biol Conserv 110:357-365

Mutschmann F, Berger L, Zwart P, Gaedicke C (2000) Chytridiomykose bei Amphibien-erstmaliger Nachweis für Europa. Berl Muench Tieraerztl Wochenschr 113:380-383

Paraense WL (1992) Halipegus dubius Klein, 1905 (Trematoda, Hemiuridae): a redescription, with notes on the working of the ovarian complex. Mem Inst Oswaldo Cruz 87(Suppl 1):179-190

Pessier AP, Nichols DK, Longcore JC, Fuller MS (1999) Cutaneous chytridiomycosis in poison dart frogs (Dendrobates spp.) and White's tree frogs (Litoria caerulea). J Vet Diagn Invest 11:194-199

Piotrowski JS, Annis, SL, Longcore JC (2004) Physiology of

Editorial responsibility: Peernel Zwart,

Utrecht, The Netherlands
Batrachochytrium dendrobatidis, a chytrid pathogen of amphibians. Mycologia 96:9-15

Rodrigues HDO, Rodrigues SS, Faria Z (1990) Contributions to the knowledge of the helminthological fauna of vertebrates of Marica, Rio de Janeiro State, Brazil. Mem Inst Oswaldo Cruz 85(1):115-116

Ron SR, Merino A (2000) Declinación de anfibios del Ecuador: Información general y primer reporte de Chytridiomycosis para Sudamérica. Froglog 42:2; available at: www. open.ac.uk/daptf/froglog/

Ronco A, Camilión C, Manassero M (2001) Geochemistry of heavy metals in bottom sediments from streams of the Río de La Plata estuary, Argentina. Environ Geochem Health 23:89-103

Seimon TA, Hoernig G, Sowell P, Halloy S, Seimon A (2005) Identification of Chytridiomycosis in Telmatobius marmoratus at $4450 \mathrm{~m}$ in the Cordillera Vilcanto of Southern Peru. In: Lavilla EO, De la Riva I (eds) Studies on the Andean frogs of the genera Telmatobius and Batrachophrynus. Asociación Herpetológica Española, Monografías de Herpetología 7, Valencia (in press)

Sona L, Vivas A, Nicora O, Di Tada I, Ibáñez N (1989) Ciclo reproductor de Leptodactylus ocellatus hembra en Embalse Río Tercero, Córdoba. Bol Asoc Herpetol Argentina 5(3):7

Speare R, Berger L (2004) Global distribution of chytridiomycosis in amphibians. Available at: www.jcu.edu.au/school/ phtm/PHTM/frogs/chyglob.htm, April 2004

Submitted: August 28, 2004; Accepted: October 31, 2004 Proofs received from author(s): April 19, 2005 